\title{
Connexin36 contributes to INS-1E cells survival through modulation of cytokine-induced oxidative stress, ER stress and AMPK activity
}

\author{
F Allagnat ${ }^{1}$, P Klee $^{2}$, AK Cardozo ${ }^{3}$, P Meda ${ }^{2}$ and J-A Haefliger ${ }^{*, 1}$
}

Cell-to-cell communication mediated by gap junctions made of Connexin36 (Cx36) contributes to pancreatic $\beta$-cell function. We have recently demonstrated that $\mathrm{C} \times 36$ also supports $\beta$-cell survival by a still unclear mechanism. Using specific $\mathrm{C} \times 36$ siRNAs or adenoviral vectors, we now show that $\mathrm{C} \times 36$ downregulation promotes apoptosis in INS-1E cells exposed to the pro-inflammatory cytokines (IL-1 $\beta$, TNF- $\alpha$ and IFN- $\gamma$ ) involved at the onset of type 1 diabetes, whereas $\mathrm{Cx} 36$ overexpression protects against this effect. Cx36 overexpression also protects INS-1E cells against endoplasmic reticulum (ER) stress-mediated apoptosis, and alleviates the cytokine-induced production of reactive oxygen species, the depletion of the ER $\mathrm{Ca}^{2+}$ stores, the CHOP overexpression and the degradation of the anti-apoptotic protein Bcl-2 and Mcl-1. We further show that cytokines activate the AMP-dependent protein kinase (AMPK) in a NO-dependent and ER-stress-dependent manner and that AMPK inhibits Cx36 expression. Altogether, the data suggest that $\mathrm{Cx} 36$ is involved in $\mathrm{Ca}^{2}{ }^{+}$homeostasis within the ER and that $\mathrm{Cx} 36$ expression is downregulated following ER stress and subsequent AMPK activation. As a result, cytokine-induced $\mathrm{C} \times 36$ downregulation elicits a positive feedback loop that amplifies ER stress and AMPK activation, leading to further Cx36 downregulation. The data reveal that Cx36 plays a central role in the oxidative stress and ER stress induced by cytokines and the subsequent regulation of AMPK activity, which in turn controls $\mathrm{Cx} 36$ expression and mitochondria-dependent apoptosis of insulin-producing cells.

Cell Death and Differentiation (2013) 20, 1742-1752; doi:10.1038/cdd.2013.134; published online 4 October 2013

The fine-tuning of insulin secretion in response to nutrient stimulation requires a tight coordination of pancreatic $\beta$-cells, which is achieved by multiple mechanisms. ${ }^{1,2}$ The direct intercellular communication provided by connexin-made gap junctions is key to integrate individual cells into coordinated multicellular units. ${ }^{1,2}$ Gap junction-mediated intercellular communication also modulates apoptosis in a variety of systems, even though the effect may be anti- or proapoptotic, depending on the connexin isoform and the cell type. ${ }^{3}$ We recently reported that mice lacking Connexin36 (Cx36), the sole connexin expressed in $\beta$-cells, ${ }^{1,2}$ are sensitized to cytotoxic drugs and cytokines, whereas mice overexpressing $\mathrm{C} \times 36$ in $\beta$-cells are more resistant to these insults. ${ }^{4}$ However, the molecular mechanism of this protection remains to be established.

Type 1 diabetes (T1D) originates from the autoimmune destruction of pancreatic $\beta$-cells, mostly through apoptosis induced by pro-inflammatory Th1 cytokines (interleukine-1 beta (IL-1 $\beta)$, tumor necrosis factor alpha (TNF- $\alpha$ ) and interferon gamma (IFN- $\gamma)$ ) and other pro-apoptotic mediators released by or expressed at the surface of the immune cells infiltrating the islets of Langerhans. ${ }^{5}$ Increasing evidence suggests a combined involvement of endoplasmic reticulum (ER) stress, oxidative stress and mitochondrial dysfunction in the induction of $\beta$-cell apoptosis, ${ }^{6-8}$ as per the so-called intrinsic pathway. ${ }^{9}$ This pathway is characterized by the permeabilization of the outer mitochondrial membrane, leading to the leakage of mitochondrial proteins such as cytochrome c, which, after association with cytosolic proteins, activate the downstream caspases that ultimately trigger apoptosis. ${ }^{10,11}$ We recently showed that the C/EBP homologous protein (CHOP) and the anti-apoptotic proteins $\mathrm{Bcl}-2$ and $\mathrm{Mcl}-1$ are key to the regulation of this pathway in $\beta$-cells. ${ }^{12}$

Here, we have investigated the molecular mechanism linking Cx36 signaling to the intrinsic pathway. We show that exposure to cytokines, particularly IL-1 $\beta$, reduces $\mathrm{Cx} 36$ expression in insulin-secreting cell lines and primary $\beta$-cells. This effect is mediated by the $\mathrm{Ca}^{2+}$-dependent activation of the AMP-activated protein kinase (AMPK), a metabolic stress-sensing protein kinase responsible for coordinating

\footnotetext{
${ }^{1}$ Department of Medicine, Centre Hospitalier Universitaire Vaudois (CHUV), Lausanne. Switzerland; ${ }^{2}$ Department of Cell Physiology and Metabolism, University of Geneva, Medical Center, Geneva, Switzerland and ${ }^{3}$ Laboratoire de Médecine Expérimentale, Université Libre de Bruxelles, Brussels, Belgium

${ }^{*}$ Corresponding author: J-A Haefliger, Department of Medicine, Laboratory of Experimental Medicine, Department of Physiology, Bugnon 7a, University Hospital, CHUV 1005, Lausanne, Switzerland. Tel: + 417955685 96; Fax: + 412169255 95; E-mail: Jacques-Antoine.Haefliger@chuv.ch

Keywords: gap junctions; Connexin36; cytokines; apoptosis; AMPK; pancreatic beta-cells

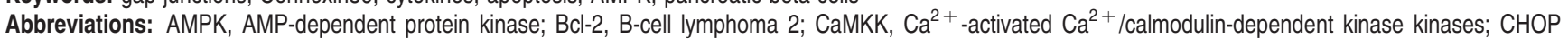
C/EBP, homologous protein, also known as GADD153 and DDIT3 (DNA damage inducible transcript 3); CRE, cAMP responsive elements; CRTC2, CREB-regulated transcription coactivator 2, also known as Torc2; CX36, connexin36; Gjd2, gap junction delta 2; ER, endoplasmic reticulum; ICER, inducible cAMP early repressor; IL-1 $\beta$, interleukin 1 beta; IFN- $\gamma$, interferon gamma; iNOS, inducible nitric oxide synthase; LKB1, also known as serine-threonine kinase 11 (STK11); Mcl-1, myeloid cell leukemia sequence 1; NAC, N-acetyl cystein; NO, nitric oxide; RNS, reactive nitrogen species; ROS, reactive oxygen species; T1D, type 1 diabetes; T2D, type 2 diabetes; TNF- $\alpha$, tumor necrosis factor alpha; siRNA, small interference RNA; SNP, sodium nitroprusside

Received 12.6.13; revised 21.8.13; accepted 25.8.13; Edited by L Scorrano; published online 04.10.13
} 
a

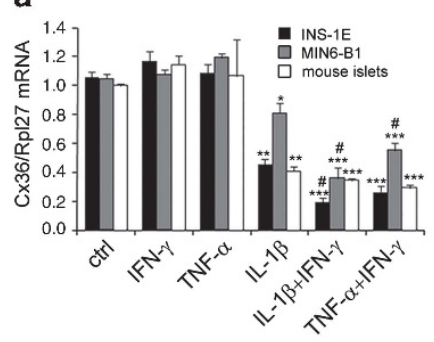

d

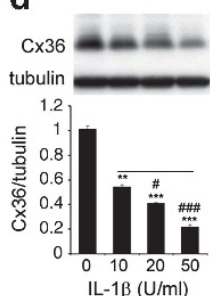

b

e

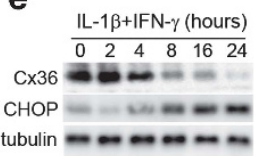

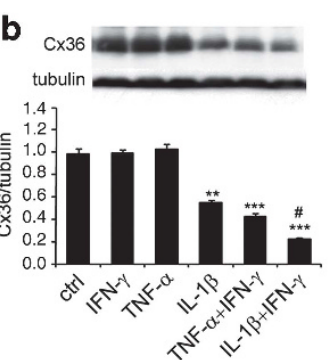

f
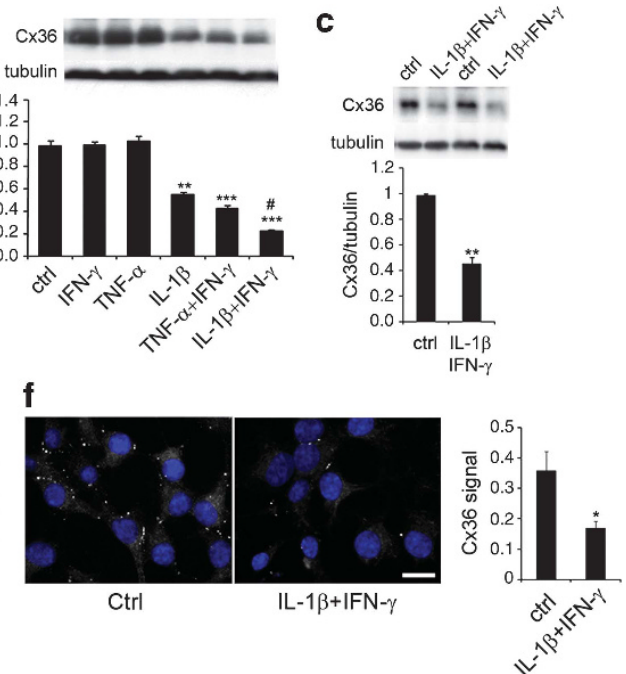

Figure 1 Pro-inflammatory cytokines downregulate $\mathrm{C} \times 36$ in $\beta$-cells. (a) Cx36 over Rpl27 transcript levels in INS-1E cells, MIN6-B1 cells and primary mouse islets cultured for $24 \mathrm{~h}$ in the presence or absence (ctrl) of IL-1 $\beta(10 \mathrm{U} / \mathrm{ml})$, TNF- $\alpha(1000 \mathrm{U} / \mathrm{ml})$ and/or IFN- $\gamma(100 \mathrm{U} / \mathrm{ml})$, alone or in combination as indicated. Data are mean \pm S.E.M. of $4-6$ independent experiments. (b) Upper panel: representative western blot analysis of Cx36 and tubulin in INS-1E cells cultured for $24 \mathrm{~h}$ in the presence or absence (ctrl) of IL-1 $\beta$, TNF- $\alpha$ and/or IFN- $\gamma$, alone or in combinations. Lower panel: quantitative assessment of five independent experiments. (c) Western blot analysis and quantitative assessment of $\mathrm{Cx} 36$ over tubulin in primary rat islets cultured for $24 \mathrm{~h}$ in the presence of IL-1 $\beta+\mathrm{IFN}-\gamma . n=4$. (d) Western blot analyses and quantitative assessment of $\mathrm{Cx} 36$ over tubulin in INS-1E cells cultured for $24 \mathrm{~h}$ in the presence of increasing concentrations of IL-1 $\beta$ as indicated. (e) Time-course analysis of Cx36, CHOP and tubulin in INS-1E cells cultured in the presence of IL-1 $\beta+$ IFN- $\gamma$ (representative of three independent experiments). (f) $\mathrm{Cx} 36$ immunolabeling dots (white dots) and DAPI (nuclear staining in blue) of INS-1E cells cultured in the presence of IL- $1 \beta+$ IFN- $\gamma$ for $24 \mathrm{~h}$. White bar: $10 \mu \mathrm{m} .{ }^{*} P<0.05$; ${ }^{*} P<0.01 ;{ }^{* \star} P<0.001$ versus ctrl ${ }^{\#} P<0.05$; ${ }^{\# \# \#} P<0.0001$ versus IL-1 $\beta$ or TNF- $\alpha$ alone

metabolism and energy demands. ${ }^{13}$ In turn, AMPK inhibits the CREB-regulated transcription coactivator 2 (Crtc2), leading to a decrease in the promoter activity of the Cx36 gene GJD2. We further document that low levels of Cx36 increase the effects of ER stress and AMPK activation, leading to a further downregulation of $\mathrm{C} \times 36$ and enhanced $\beta$-cell apoptosis. The data provide evidence that $\mathrm{C} \times 36$ modulates $\mathrm{ER} \mathrm{Ca}^{2+}$ homeostasis and molecular components of the intrinsic mitochondrial pathway of apoptosis, which ultimately regulate the death of insulin-producing $\beta$-cells.

\section{Results}

Cytokines reduce Cx36 expression and function in insulin-producing cells and primary mouse islets. To evaluate the effect of the pro-inflammatory cytokines on Cx36 expression, insulin-producing cells and primary mouse islets were treated with IL- $1 \beta$, TNF- $\alpha$ and IFN- $\gamma$, alone or in combination. Supplementary Figure $\mathrm{S} 1$ shows that a $24-\mathrm{h}$ exposure to $1000 \mathrm{U} / \mathrm{ml}$ TNF- $\alpha$ or $100 \mathrm{U} / \mathrm{ml} \mathrm{IFN-} \gamma$ did not affect insulin-secreting cells viability. In contrast, $10 \mathrm{U} / \mathrm{ml} \mathrm{IL}-1 \beta$ significantly increased insulin-secreting cells apoptosis in both primary islets and insulin-producing cell lines (Supplementary Figure S1). The combination of TNF- $\alpha$ and IFN- $\gamma$ significantly decreased viability levels in all models, and the addition of IFN- $\gamma$ potentiated the negative effect of $\mathrm{IL}-1 \beta$ (Supplementary Figure S1). We then studied the Cx36 mRNA regulation in the same conditions and observed that Cx36 mRNA levels are closely correlated with cell survival in all models (Figure 1a). TNF- $\alpha+$ IFN- $\gamma$ also decreased $\mathrm{Cx} 36$ protein levels, and IFN- $\gamma$ potentiated the effect of IL-1 $\beta$ alone,
Table 1 Dye coupling of INS-1E cells after a $24 \mathrm{~h}$ exposure to either IL-1 $\beta$ or metformin

\begin{tabular}{llccc}
\hline Condition & $\begin{array}{c}\text { Extent of } \\
\text { coupling }^{\text {a }}\end{array}$ & $\begin{array}{c}\text { Incidence } \\
\text { of } \\
\text { coupling }\end{array}$ & $\begin{array}{c}\text { Coupling } \\
\text { index (a.u.) }\end{array}$ & $\begin{array}{c}\text { Number of } \\
\text { microinjections }\end{array}$ \\
\hline Control & $2.5 \pm 0.2$ & $28(65.1)$ & 162.1 & 43 \\
IL-1 $\beta$ & $1.5 \pm 0.1^{\star * \star}$ & $12(41.4)^{\star}$ & 60.0 & 29 \\
Metformin & $1.4 \pm 0.1^{\star \star *}$ & $8(32.0)^{\star *}$ & 43.5 & 25 \\
\hline
\end{tabular}

${ }^{a}$ Data are mean \pm S.E.M. values of the number of cells featuring labeling by Lucifer yellow, in the number of microinjections indicated in the right column. ${ }^{* * *} P<0.001$ compared with the value in control cells, as evaluated by ANOVA. ${ }^{b}$ Number and (proportion) of injections resulting in the intercellular transfer of the dye. ${ }^{*} P<0.04,{ }^{* \star} P<0.008$ versus control as evaluated by the non parametric $\chi^{2}$-test.

${ }^{\circ}$ Given by average extent $\chi$ percentage of coupling.

both in INS-1E cells and primary mouse islets (Figures $1 \mathrm{~b}$ and $\mathrm{c}$ ). IL-1 $\beta$ decreased the protein levels of $\mathrm{Cx} 36$ in a dosedependent manner (Figure 1d). Time-course experiments further revealed that IL-1 $\beta+\mathrm{IFN}-\gamma$ time-dependently decreased the Cx36 protein expression in INS-1E cells (Figure 1e). Consistently, a 24-h cytokine treatment decreased the typical punctate immunostaining of Cx36 in INS-1E cells (Figure 1f). These conditions also resulted in a significant decrease in both the extent and the incidence of INS-1E coupling, as evaluated by the intercellular exchange of the gap junction tracer Lucifer Yellow (Table 1).

The levels of Cx36 influence apoptosis and the production of reactive oxygen and nitrogen species in INS-1E cells. To investigate the involvement of Cx36 in cytokine-induced apoptosis, we used siRNA and adenoviral 
a

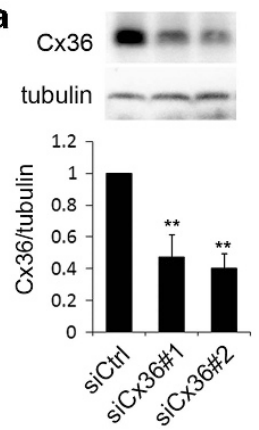

c

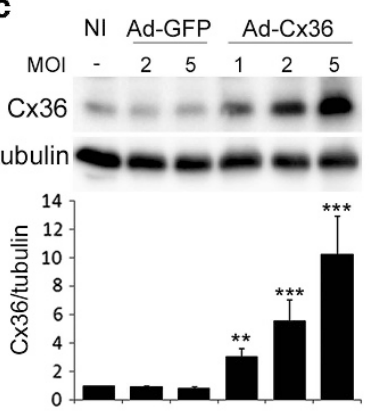

b

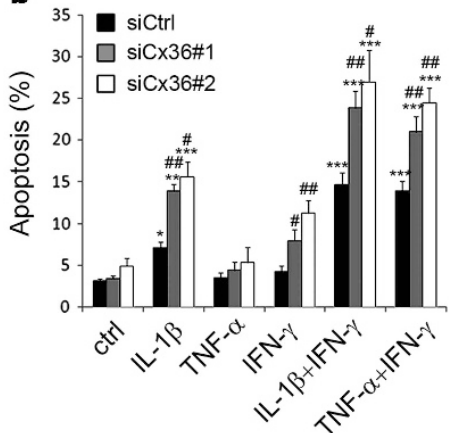

d $\quad$ NI

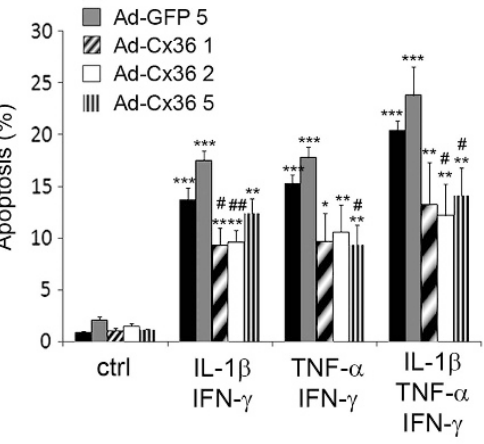

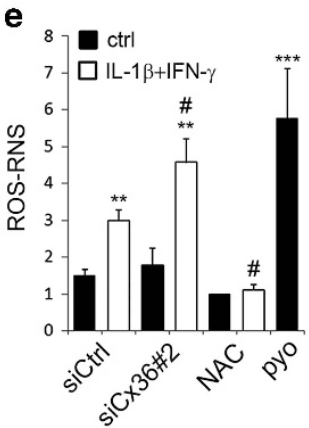

f

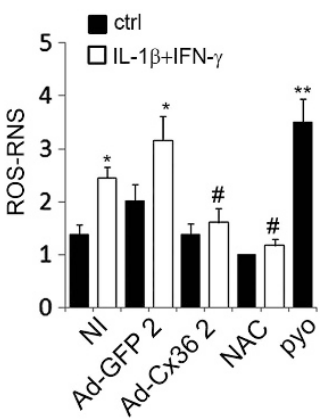

Figure 2 Changes in Cx36 expression modulate the cytokine-induced ROS-RNS production and apoptosis of INS-1E cells. (a, b and e) INS-1E cells were transfected with a control siRNA (siCtrl) or two different Cx36 siRNAs (siCx36\#1 and \#2). (c, $\mathbf{d}$ and f) INS-1E cells were infected or not (NI) with a control adenovirus (Ad-GFP) or a rat Cx36 adenovirus (Ad-Cx36) at various multiplicity of infection (MOI), as indicated. (a and c) Western blot analysis of Cx36 over tubulin levels. (b and d) Prevalence of apoptosis was evaluated by Hoechst-PI staining in cells treated or not (ctrl) for $24 \mathrm{~h}$ with IL-1 $\beta$, TNF- $\alpha$ and/or IFN- $\gamma$, alone or in combination, as indicated. (e and f) ROS-RNS production was evaluated in live cells treated for $15 \mathrm{~h}$ with IL-1 $\beta+\mathrm{IFN}-\gamma$, together or not with $1 \mathrm{mM} \mathrm{N}$-acetyl cystein (NAC), or in cells treated for 30 min with $200 \mu \mathrm{M}$ pyocyanin (pyo). ${ }^{*} P<0.05,{ }^{* *} P<0.01,{ }^{* * *} P<0.001$ versus ctrl. ${ }^{\#} P<0.05,{ }^{\# \#} P<0.01$ versus siCtrl-transfected or $\mathrm{NI}$ condition

transfer strategies to modulate its content. Two distinct siRNAs targeting Cx36 mRNA induced a $60 \%$ decrease in Cx36 mRNA and protein levels in INS-1E cells (Supplementary Figures S2 and 3a). This knockdown did not alter the apoptosis of control or TNF- $\alpha$-treated INS-1E cells (Figure $2 b$ ) but significantly increased the apoptosis induced by IL- $1 \beta$, TNF- $\alpha+\mathrm{IFN}-\gamma$ or IL- $1 \beta+\mathrm{IFN}-\gamma$, and sensitized the INS-1E cells to IFN- $\gamma$ alone (Figure 2b). Conversely, the adenoviral-mediated overexpression of Cx36 (Figure 2c) significantly reduced the apoptosis induced by TNF- $\alpha+$ IFN- $\gamma$, IL- $1 \beta+$ IFN- $\gamma$ or a combination of the three cytokines (Figure 2d).

A 15-h IL-1 $\beta$ + IFN- $\gamma$ treatment did not trigger the formation of superoxide species (data not shown), but stimulated the production of ROS-RNS, which was fully inhibited by $1 \mathrm{mM}$ of the antioxidant $\mathrm{N}$-acetyl-cystein (Figures $2 \mathrm{e}$ and f). Knockdown of Cx36 increased IL-1 $\beta+$ IFN- $\gamma$-induced ROS-RNS production (Figure $2 \mathrm{e}$ ), whereas the overexpression of $\mathrm{Cx} 36$ prevented it (Figure 2f). As a positive control for ROS-RNS and superoxide production, INS-1E cells were treated for 30 min with $200 \mu \mathrm{M}$ of the ROS inducer pyocyanin, which induced a 3-5 fold increase in ROS-RNS production.

Cx36 modulates the mitochondrial pathway of apoptosis. Release of mitochondrial cytochrome $c$ into the cytoplasm is a known feature of the mitochondrial pathway of apoptosis. ${ }^{14}$ We assessed cytochrome c distribution by immunofluorescence in INS-1E cells treated with IL- $1 \beta+$ IFN- $\gamma$ for $15 \mathrm{~h}$ and observed four distinct patterns (Figure 3a). Live (L) cells featured the typical mitochondrial network staining, whereas apoptotic cells, identified by nucleus morphology using DNA staining by Hoechst, displayed either a diffuse cytosolic cytochrome c staining (A), a discrete pattern typical of fragmented mitochondria that still retain cytochrome c (B), or occasionally no cytochrome c staining (C) (Figure 3a, left panel). Quantitative analysis revealed that about $60 \%$ of the apoptotic cells featured cytosolic cytochrome $\mathrm{c}$ and this fraction was significantly reduced in cells overexpressing Cx36 (Figure 3a, right panel). Western blots of Bcl-2 and $\mathrm{Mcl}-1$ confirmed that the levels of these proteins were significantly decreased after a 15-h treatment with IL-1 $\beta+$ IFN- $\gamma$ (Figures $3 \mathrm{~b}$ and c). Cx36 knockdown using siCx36\#2, which was the most efficient siRNA (Figures 2 and $3)$, significantly decreased basal $\mathrm{Mcl}-1$ and $\mathrm{Bcl}-2$ levels and tended to aggravate the cytokine-induced $\mathrm{Mcl}-1$ and $\mathrm{Bcl}-2$ decrease (Figure 3b). In contrast, Cx36 overexpression restored $\mathrm{Bcl}-2$ levels and increased $\mathrm{Mcl}-1$ levels in cells treated with IL- $1 \beta+\mathrm{IFN}-\gamma$ (Figure 3c).

Cx36 overexpression increases ER $\mathrm{Ca}^{2+}$ store and prevents $\mathrm{ER} \mathrm{Ca}^{2+}$ store depletion upon cytokine treatment. We previously showed that cytokines induce a 

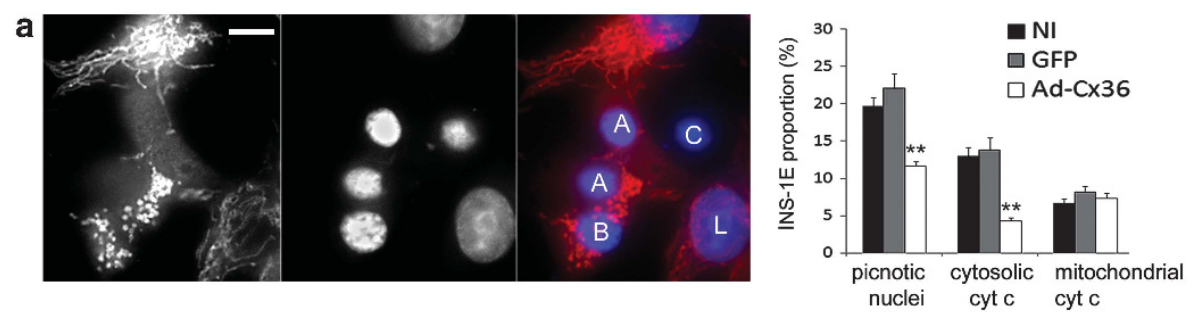

b
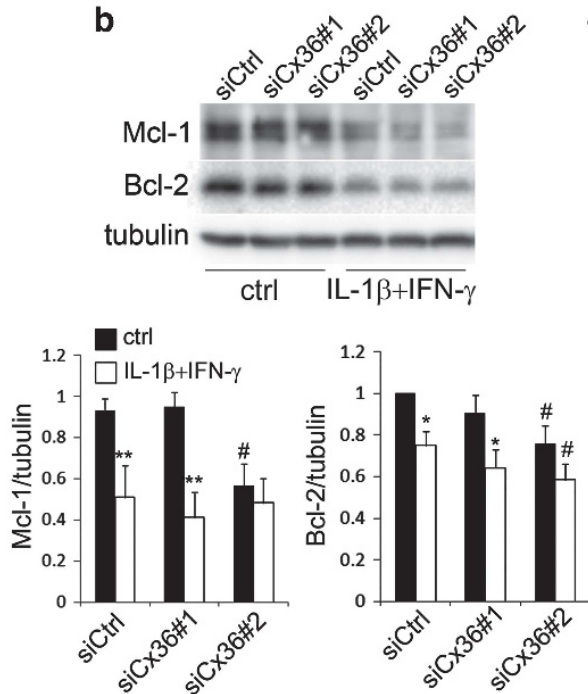
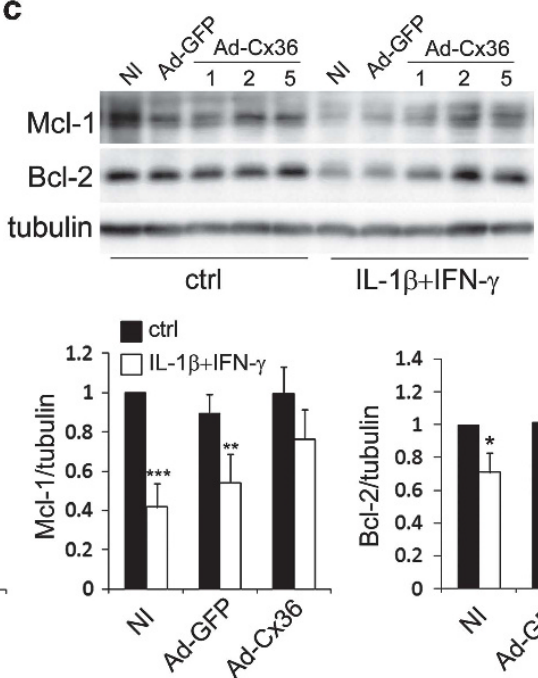

Figure 3 Changes in Cx36 expression modulate the mitochondrial pathway of apoptosis in INS-1E cells. (a) INS-1E cells were infected or not (NI) with Ad-CX36 at MOI 2 . Representative cytochrome c immunostaining (red) and DAPI (blue nuclear staining) upon IL-1 $\beta+$ IFN- $\gamma$-induced apoptosis (left panel) and quantitative assessment of picnotic nuclei and cytosolic or mitochondrial cytochrome c staining pattern (right panel). White bar: $5 \mu \mathrm{m}$. L: live cell; A: apoptotic cell with cytochrome c release; B: apoptotic cell without cytochrome $\mathrm{c}$ release; $\mathrm{C}$ : apoptotic cell without cytochrome c. (b) INS-1E cells were transfected with a control siRNA (siCtrl) or two different Cx36 siRNA (siCx36\#1 and \#2) and treated for $15 \mathrm{~h}$ with IL-1 $\beta+\mathrm{IFN}-\gamma$. Representative western blot for Bcl-2 and Mcl-1 over tubulin and quantitative assessment (means $\pm \mathrm{S}$.E.M.) of Mcl-1/tubulin (left panel) and Bcl-2/tubulin (right panel) levels from five independent experiments. ${ }^{*} P<0.05,{ }^{* \star} P<0.01$ versus ctrl. ${ }^{\#} P<0.05$ versus respective siCtrl condition. (c) INS-1E cells were infected or not (NI) with a control virus (Ad-GFP) or a Cx36 virus (Ad-Cx36) and treated for $15 \mathrm{~h}$ with IL-1 $\beta+\mathrm{IFN}-\gamma$. Representative western blot for Bcl-2 and Mcl-1 over tubulin and quantitative assessment (means \pm S.E.M.) of Mcl-1/tubulin (left panel) and Bcl-2/tubulin (right panel) levels from six independent experiments (Ad-GFP and Ad-Cx36 at MOI2). ${ }^{*} P<0.05,{ }^{* *} P<0.01,{ }^{* * *} P<0.01$ versus ctrl. ${ }^{\#} P<0.05$ versus respective $\mathrm{NI}$ condition

depletion of the ER $\mathrm{Ca}^{2+}$ stores, ${ }^{15}$ leading to ER stress and $\beta$-cell apoptosis. ${ }^{12,16}$ In an attempt to measure ER $\mathrm{Ca}^{2+}$, INS-1E cells loaded with the cytosolic $\mathrm{Ca}^{2+}$ indicator Fura-2 were maintained in $\mathrm{KRBH}$ medium without $\mathrm{Ca}^{2+}$ and treated with $5 \mu \mathrm{M}$ thapsigargin to induce the leaking of the cation out of the ER. ${ }^{15}$ This resulted in a rapid rise of cytosolic $\left[\mathrm{Ca}^{2+}\right]_{\mathrm{i}}$, which depends on the $\mathrm{Ca}^{2+}$ concentration in this organelle (Figure $4 a) .^{15}$ This first phase was followed by a second 'descending' phase where $\left[\mathrm{Ca}^{2+}\right]_{i}$ returned to the basal level, which directly reflects the $\mathrm{Ca}^{2+}$ buffering/ export capacities of the cells. ${ }^{17,18}$ INS-1E cells treated for $15 \mathrm{~h}$ with $\mathrm{IL}-1 \beta+\mathrm{IFN}-\gamma$ displayed a reduced thapsigargininduced $\left[\mathrm{Ca}^{2+}\right]_{\mathrm{i}}$ increase (Figure $4 \mathrm{a}$ ), indicating that cytokines depleted the $\mathrm{ER} \mathrm{Ca}^{2+}$ stores as previously shown. ${ }^{15}$ Of note, $\mathrm{Ca}^{2+}$ buffering/export was slower in cytokinetreated cells, suggesting that cytokines also affected the cytosolic buffering capacity of the cells. Cx36 overexpression significantly increased the amplitude of the thapsigargin-induced release of $\mathrm{Ca}^{2+}$ from the $\mathrm{ER}$ and prevented the overall release of $\mathrm{ER} \mathrm{Ca}^{2+}$ in cytokine-treated cells (Figure 4a). However, Cx36 overexpression did not have an impact on the slope of the second 'descending' phase of the curve, suggesting that $\mathrm{Cx} 36$ overexpression did not alter the kinetics of $\mathrm{Ca}^{2+}$ buffering/export, in control or in cytokinetreated conditions (Figure 4a).

Interestingly, Cx36 knockdown sensitized, whereas Cx36 overexpression protected INS-1E cells against apoptosis induced by a 15-h treatment with the chemical ER stressors thapsigargin $(100 \mathrm{nM})$ or tunicamycin $(5 \mu \mathrm{g} / \mathrm{ml})$ or the $\mathrm{Ca}^{2+}$ ionophore A23187 (1 $\mu \mathrm{M})$ (Supplementary Figures S3a and b). Western blot analyses of the ER-stress marker $\mathrm{CHOP}$ revealed that $\mathrm{Cx} 36$ knockdown aggravated the cytokineinduced CHOP overexpression (Figure $4 \mathrm{~b}$ and Supplementary Figure S3c), whereas Cx36 overexpression reduced it (Figure 4c and Supplementary Figure S3d). Similar effects were observed on thapsigargin-induced $\mathrm{CHOP}$ overexpression (Figures $4 \mathrm{~d}$ and e). Of note, the amounts of cleaved caspase 3 closely correlated with those of CHOP in all experiments (Figures $4 \mathrm{~b}-\mathrm{e}$ and Supplementary Figures $\mathrm{S} 3 \mathrm{e}$ and $\mathrm{f}$ ). Altogether, these data indicate that $\mathrm{C} \times 36$ modulates in parallel $\mathrm{ER} \mathrm{Ca}^{2+}$ levels, ER stress and apoptosis of INS-1E cells.

Cx36 expression is regulated by ER stress and AMPK. $\mathrm{IL}-1 \beta+\mathrm{IFN}-\gamma$ stimulated the phosphorylation of AMPK (Figure $5 \mathrm{a}$ and Supplementary Figure S4a) in INS-1E cells and simultaneously downregulated Cx36 (Figure 5a). 

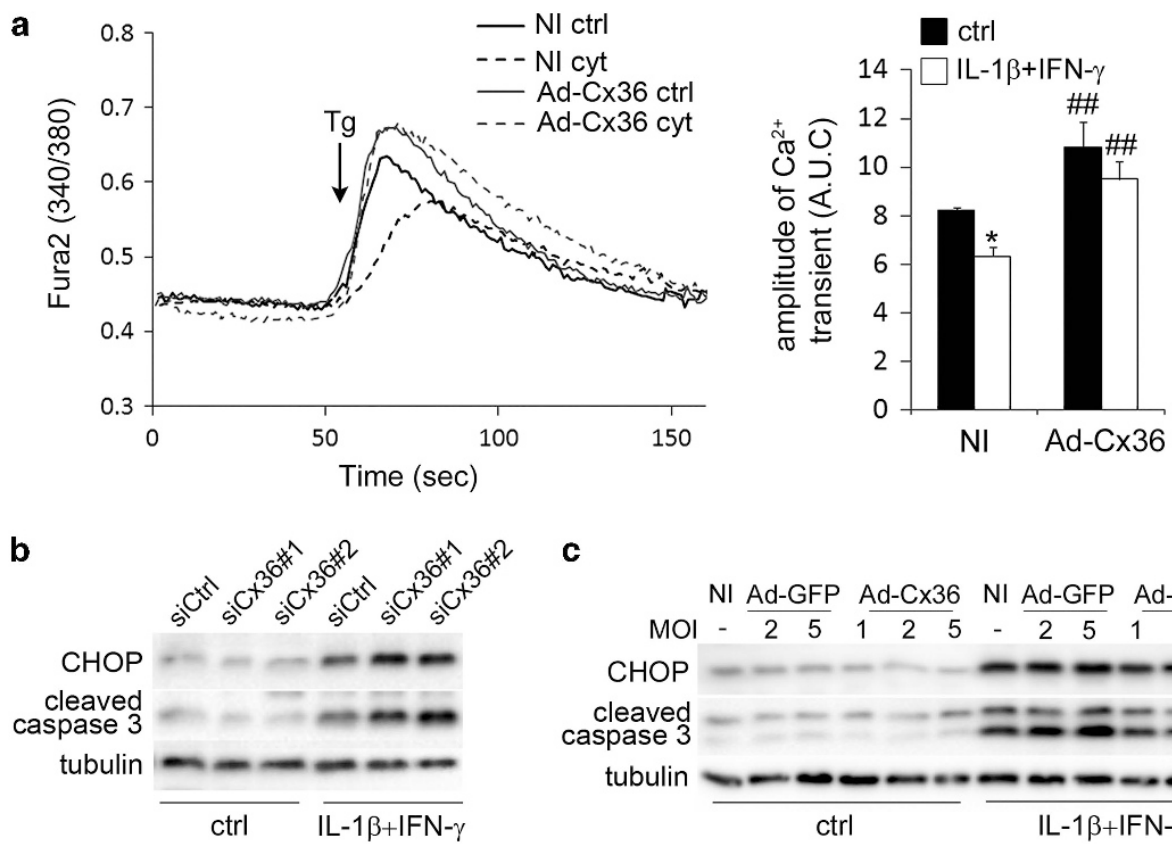

c
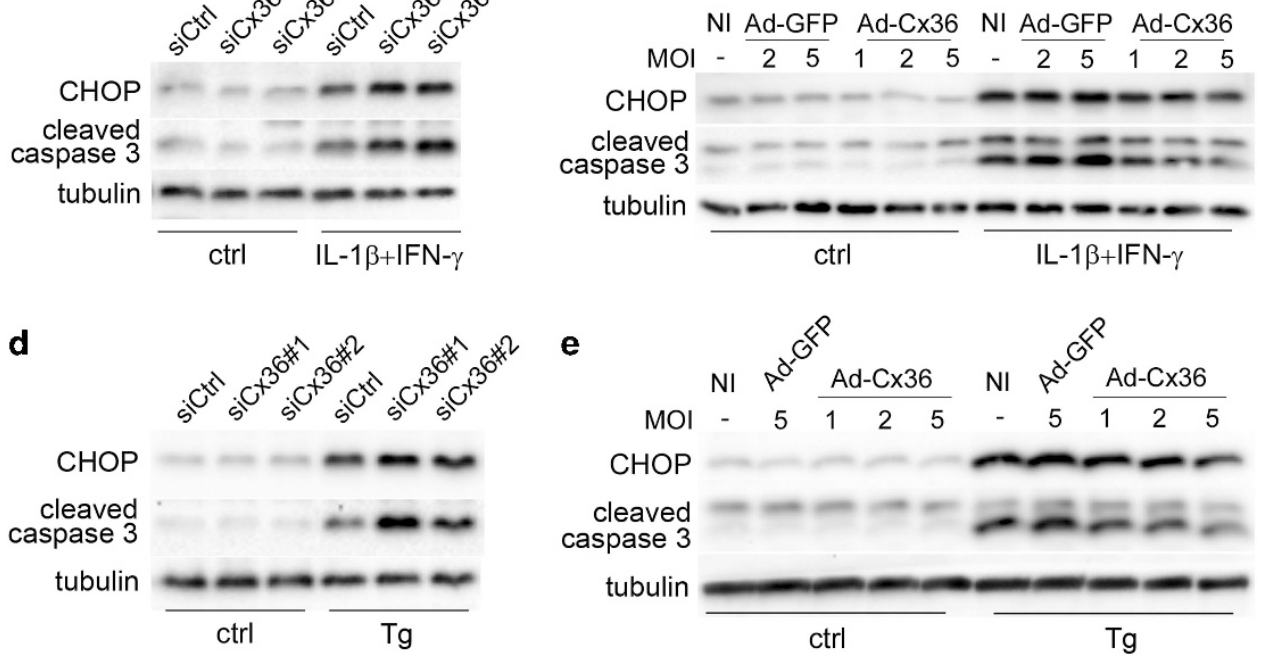

Figure 4 Changes in Cx36 expression modulate ER stress, CHOP and activate caspase 3 levels in INS-1E cells. (a) INS-1E cells were infected or not (NI) with a control adenovirus (Ad-GFP) or a rat Cx36 adenovirus (Ad-Cx36) at various multiplicity of infection (MOI), as indicated. Cells were then treated or not (ctrl) for $15 \mathrm{~h}$ with IL-1 $\beta+$ IFN- $\gamma$ (cyt), loaded with the cytosolic calcium-dye Fura-2 and monitored in $\mathrm{Ca}^{2}{ }^{2}$-free KRBH in presence of the SERCA inhibitor thapsigargin (Tg; $5 \mu \mathrm{M}$, arrow). Left panel: data are representative traces. Right panel: quantitative assessment of the cytosolic $\mathrm{Ca}^{2+}$ rise calculated by the area under the curve (A.U.C.) of four independent experiments. ${ }^{*} P<0.05$ versus ctrl condition; ${ }^{\# \#} P<$ versus respective NI condition. (b-d) Representative western blot for $\mathrm{CHOP}$ and cleaved caspase 3 over tubulin levels in INS-1E cells transfected with a control siRNA (siCtrl) or two different Cx36 siRNA (siCx36\#1 and \#2) and treated for $24 \mathrm{~h}$ with IL-1 $\beta+$ IFN- $\gamma$ (b) or for $15 \mathrm{~h}$ with thapsigargin (Tg: $100 \mathrm{nM}$; (d)). (c-e) Representative western blot for CHOP and cleaved caspase 3 over tubulin levels in INS-1E cells infected or not (NI) with a control adenovirus (Ad-GFP) or a rat Cx36 adenovirus (Ad-Cx36) at various MOI and treated for $24 \mathrm{~h}$ with IL- $1 \beta+\mathrm{IFN}-\gamma$ (c) or for $15 \mathrm{~h}$ with thapsigargin (Tg: $100 \mathrm{nM}$; (e))

Co-treatment with $20 \mu \mathrm{M}$ of the AMPK inhibitor compound C abolished the effect of IL- $1 \beta$ or IL-1 $\beta+$ IFN- $\gamma$ on both AMPK phosphorylation and $\mathrm{C} \times 36$ downregulation (Figure $5 \mathrm{~b}$ ). Metformin and AICAR, two compounds known to activate AMPK, also decreased Cx36 expression in INS-1E cells (Supplementary Figure S4b) and compound C blocked all these effects (Supplementary Figures $\mathrm{S} 4 \mathrm{C}$ and d). In agreement with these data, metformin reduced the coupling between INS1-E cells (Table 1). AMPK inhibition using an adenovirus allowing the overexpression of a dominantnegative form of the kinase (Ad-DN-AMPK) also prevented the effect of both metformin and IL-1 $\beta+$ IFN- $\gamma$ on the levels of Cx36 mRNA (Supplementary Figure S4e) and protein (Figure $5 \mathrm{c}$ ). As a positive control, we observed that the known AMPK target gene Liver-type pyruvate kinase (L-PK) was regulated like $\mathrm{C} \times 36$ after both AMPK activation and inhibition (Supplementary Figure S4e).
We then studied the mechanisms of cytokine-induced AMPK activation. Figure $5 \mathrm{~d}$ shows that the cytokine-induced AMPK phosphorylation and $\mathrm{C} \times 36$ downregulation were both inhibited by $1 \mathrm{mM}$ L-NAME (Figure $5 \mathrm{~d}$ ), suggesting an involvement of NO. In line with these data, $100 \mu \mathrm{M}$ sodium nitroprusside (SNP) mimicked the effect of cytokines on Cx36 levels and, to a limited extent, on AMPK phosphorylation (Figure $5 \mathrm{~d}$ ). Cytokines were able to phosphorylate AMPK and decrease Cx36 despite the presence of $50 \mu \mathrm{M}$ the pan-caspase inhibitor Z-VAD-FMK (Figure 5d), indicating that NO production and the regulation of AMPK and Cx36 are independent and precede apoptosis. Time-course analyses revealed that thapsigargin $(100 \mathrm{nM})$, but not tunicamycin (data not shown), controlled Cx36, CHOP expression and AMPK phosphorylation within a same time-window (Figure 5e). The $\mathrm{Ca}^{2+}$ ionophore A23197 $(1 \mu \mathrm{M})$ mimicked the effects of thapsigargin on the 
a

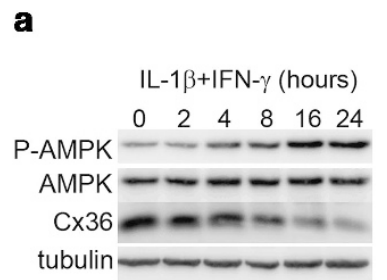

b

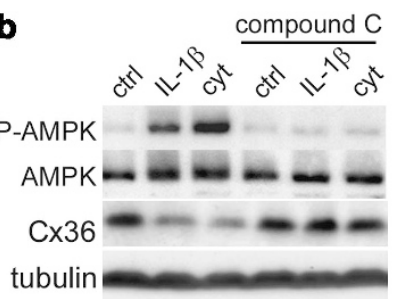

e

d

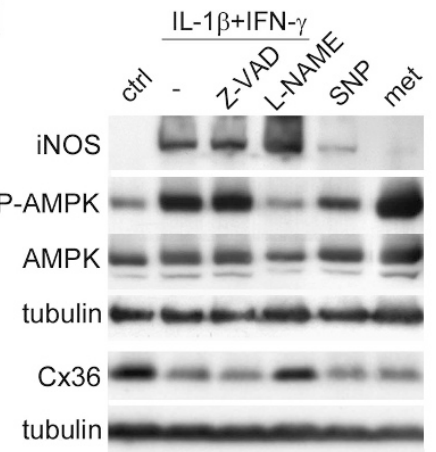

C

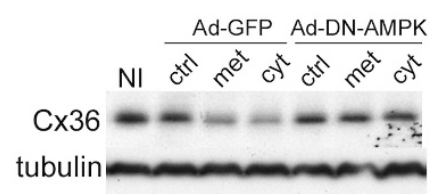

f

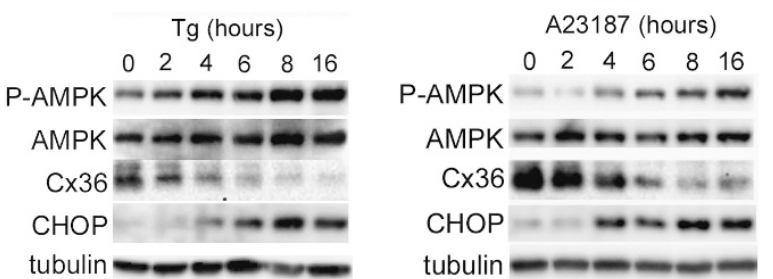

g

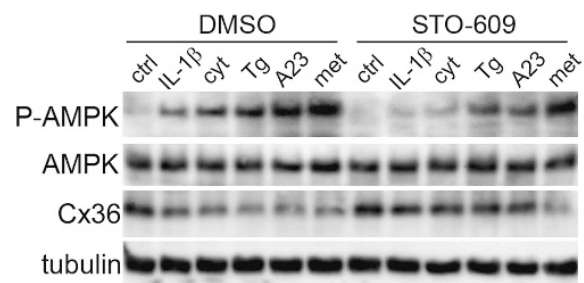

$\mathbf{h}$

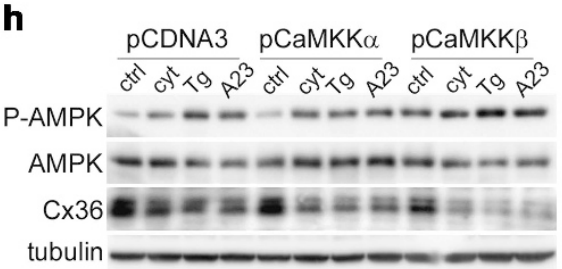

Figure 5 Cytokine-induced Cx36 downregulation requires AMPK activation in INS-1E cells. (a) Time-course analyses of P-AMPK, AMPK, Cx36 and tubulin levels in INS$1 \mathrm{E}$ cells treated with IL-1 $\beta+\mathrm{IFN} \gamma$. (b) Western blot of P-AMPK, AMPK, Cx36 and tubulin levels in INS-1E cells cultured for $24 \mathrm{~h}$ in the presence or absence (ctrl) of IL-1 $\beta$ or $\mathrm{IL}-1 \beta+\mathrm{IFN} \gamma$ (cyt), alone or in combination with the AMPK inhibitor compound C $(20 \mu \mathrm{M})$. (c) INS-1E cells were infected with a control Ad-GFP virus or a dominant-negative AMPK virus (Ad-DN-AMPK) and cultured for $24 \mathrm{~h}$ in the absence (ctrl) or presence of metformin (met; $1 \mathrm{mM}$ ) or IL-1 $\beta+$ IFN $\gamma$ (cyt). (d) Representative western blot of iNOS, P-AMPK, AMPK, Cx36 and tubulin in INS-1E cells treated for $24 \mathrm{~h}$ with IL-1 $\beta+$ IFN- $\gamma$ (cyt), alone or in combination with $1 \mathrm{mM} \mathrm{L-NAME}$ or $50 \mu \mathrm{M}$ Z-VAD, or $100 \mu \mathrm{M}$ SNP or $1 \mathrm{mM}$ metformin (met). (e and f) Time-course or dose-response analyses of P-AMPK, AMPK, Cx36 and CHOP reveal that thapsigargin and A23187 stimulated AMPK phosphorylation and Cx36 reduction in INS-1E cells. (g) Representative western blot of P-AMPK, AMPK, Cx36 and tubulin levels in INS-1E cells treated with IL-1 $\beta$, IL-1 $\beta+$ IFN- $\gamma$ (cyt), thapsigargin (Tg), A23187 (A23) or metformin (met) for $16 \mathrm{~h}$, together with DMSO or the CaMKKs inhibitor STO-609. (h) Representative western blot of P-AMPK, AMPK, Cx36 and tubulin in INS-1E cells transfected with an empty vector (ctrl) or vectors encoding either CaMKK $\alpha$ or CaMKK $\beta$, and treated for $15 \mathrm{~h}$ with $\mathrm{IL}-1 \beta+\mathrm{IFN}-\gamma$ (cyt), thapsigargin (Tg) or A23187 (A23)

expression of $\mathrm{Cx} 36$ and $\mathrm{CHOP}$ and on the phosphorylation of AMPK (Figure 5f), suggesting that cytosolic $\mathrm{Ca}^{2+}$ as a plausible link between the different conditions that control Cx36 expression.

AMPK phosphorylation/activation is controlled by several kinases. ${ }^{19}$ The $\mathrm{Ca}^{2+}$-activated $\mathrm{Ca}^{2+} /$ calmodulin-dependent kinase kinases (CaMKKs) inhibitor STO-609 ${ }^{20}$ partly blocked the effects of IL-1 $\beta+\mathrm{IFN}-\gamma$, thapsigargin $(100 \mathrm{nM})$ and A23187 $(1 \mu \mathrm{M})$, but not metformin $(1 \mathrm{mM})$, on AMPK phosphorylation and Cx36 levels (Figure $5 \mathrm{~g}$ ). In addition, transient overexpression of a constitutively active form of $\mathrm{CaMKK} \beta$, but not CaMKK $\alpha$ (Supplementary Figure S5a), increased the basal levels of P-AMPK and potentiated the effects of IL- $1 \beta+\mathrm{IFN}-\gamma$, thapsigargin and A23187 on these levels (Figure $5 \mathrm{~h}$ and Supplementary Figure S5b), enhancing the downregulation of $\mathrm{C} \times 36$ (Figure $5 \mathrm{~h}$ and Supplementary Figure S5c). In contrast, LKB1 knockdown using two siRNAs (Supplementary Figure S6a) did not affect the downregulation of $\mathrm{C} \times 36$ induced by $\mathrm{IL}-1 \beta+\mathrm{IFN}-\gamma$, thapsigargin or A23187 (Supplementary Figures S6b-d), whereas it partially blocked the effects of IL- $1 \beta+\mathrm{IFN}-\gamma$, thapsigargin and A23187 on AMPK phosphorylation (Supplementary Figures $\mathrm{S} 6 \mathrm{~b}$ and $\mathrm{c}$ ). Collectively, these experiments suggest that both LKB1 and CaMKK $\beta$ are involved in the cytokine-induced AMPK phosphorylation and that only $\mathrm{CaMKK} \beta$-mediated AMPK phosphorylation selectively leads to $\mathrm{C} \times 36$ downregulation.

Cytokine-induced $\mathrm{C} \times 36$ downregulation triggers a positive feedback loop of AMPK activation. Cx36 downregulation aggravates ER stress (Figure 3), and cytokine-induced ER stress stimulates AMPK phosphorylation, leading to $\mathrm{C} \times 36$ downregulation (Figure 5). We tested the effect of Cx36 knockdown or overexpression on cytokine-induced AMPK phosphorylation. Cx36 knockdown increased cytokine-induced P-AMPK levels, whereas Cx36 overexpression slightly decreased the P-AMPK levels (Figures $6 a$ and $b$ ). 
Cytokines inhibit Cx36 transcription via a cAMP response element in the GJD2 promoter. The stability of the Cx36 transcript was not altered by a 15-h exposure

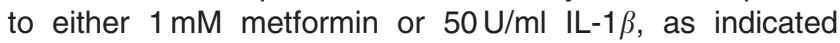
by the time-course treatments with $5 \mu \mathrm{g} / \mathrm{ml}$ actinomycin $D$,
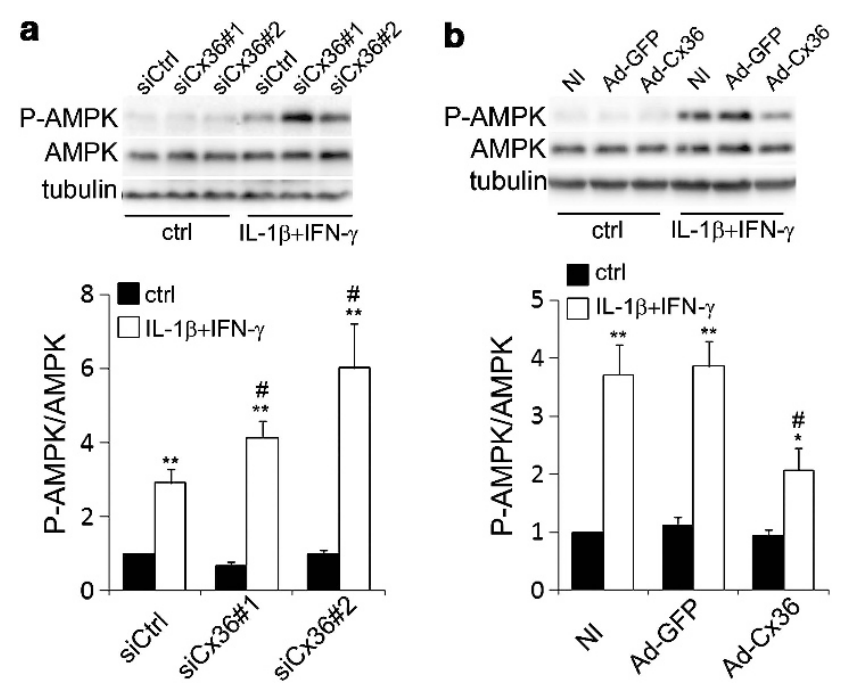

Figure 6 Changes in Cx36 expression modulate ER stress-induced phosphorylation of AMPK in INS-1E cells. (a) Representative western blot and quantification of P-AMPK over AMPK levels in INS-1E cells transfected with a control siRNA (siCtrl) or two different Cx36 siRNAs (siCx36\#1 and \#2) and treated for $24 \mathrm{~h}$ with IL-1 $\beta+\mathrm{IFN}-\gamma$. (b) Representative western blot and quantification of P-AMPK over AMPK levels in INS-1E cells infected or not (NI) with the Ad-GFP or the Ad-Cx36 at various multiplicity of infection (MOI), as indicated, and treated for $24 \mathrm{~h}$ with $\mathrm{IL}-1 \beta+\mathrm{IFN}-\gamma .{ }^{*} P<0.05,{ }^{*} P<0.01$ versus ctrl. ${ }^{\#} P<0.05$ versus respective siCtrl condition or $\mathrm{NI}$ condition suggesting that the AMPK-dependent control of Cx36 occurs at the transcriptional level (Figure 7a).

To identify the region of the Cx36 gene responsible for the AMPK effect, INS-1E cells were transiently transfected with four fragments of the promoter of the human Cx36 gene GJD2 and then exposed for $24 \mathrm{~h}$ to either $1 \mathrm{mM}$ metformin, $50 \mathrm{U} / \mathrm{ml}$ IL- $1 \beta$ or $10 \mathrm{U} / \mathrm{ml} \mathrm{IL-1} \beta+100 \mathrm{U} / \mathrm{ml}$ IFN- $\gamma$. All constructs, but the pGL3-316, displayed a $20-30 \%$ reduction in the response to both metformin and cytokines. Mutation of a cAMP response element (CRE) involved in the transcriptional activity of $G J D 2^{21,22}$ restored the activity of the GJD2 promoter in response to all treatments (Figure $7 \mathrm{~b}$ ). AMPK hampers CRE activities by inhibiting the nuclear translocation of the Crtc2. ${ }^{23,24}$ Transient overexpression of mouse Crtc2 (Figure 7c) stimulated the activity of the wild type GJD2 promoter but not that of the promoter containing the CRE-mutated fragment (Figure 7d). Furthermore, Crtc2 overexpression restored the $\mathrm{Cx} 36$ transcript levels to the control value in INS-1E cells treated with IL- $1 \beta+$ IFN- $\gamma$ (Figure 7e).

\section{Discussion}

We have previously shown that loss of the native gap junction protein Cx36 sensitizes pancreatic $\beta$-cells to death in mice models of hyperglycemia induced in vivo by the administration of either alloxan or streptozotocin, and that, conversely, the experimental overexpression of $\mathrm{Cx} 36$ protects against these insults. ${ }^{4} \mathrm{C} \times 36$ also protects pancreatic $\beta$-cells in vitro against apoptosis induced by lipids ${ }^{22,25}$ and cytokines. ${ }^{4}$ Although these studies suggest a common pathway for Cx36-mediated protection against various cytotoxic insults both in vitro and in vivo, the molecular mechanisms activating this pathway remain to be unraveled. The aim of this study was to identify
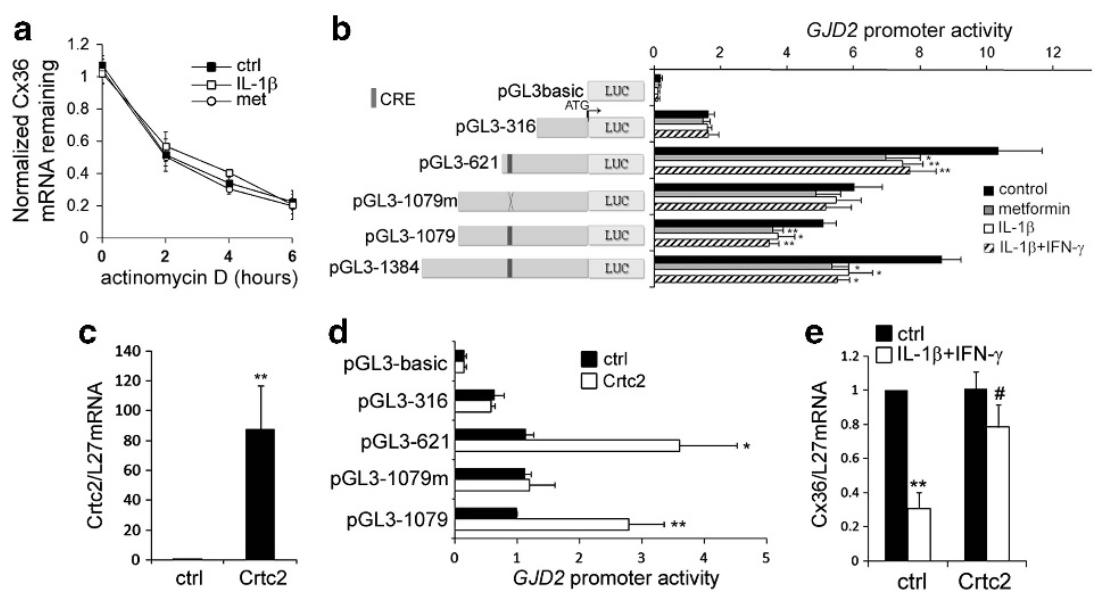

Figure 7 Crtc2 is involved in cytokine-induced inhibition of Cx36 transcriptional activity. (a) INS-1E cells were incubated for 2, 4 or $6 \mathrm{~h}$ in the absence (ctrl; black squares) or presence of IL-1 $\beta$ (white squares) or metformin (white circles), together or not (t0) with the transcription inhibitor actinomycin D. Data are means \pm S.E.M. of Cx36/L27 mRNA levels assessed by qPCR in three independent experiments. (b) INS-1E cells were cotransfected with a plasmid expressing the reporter gene luciferase under the control of progressive deletions of the human GJD2 promoter, including one construct with a mutated CRE (pGL3-1079m). After transfection, cells were incubated for $24 \mathrm{~h}$ in absence (control; black bars) or presence of metformin (gray bars), IL-1 $\beta$ (white bars) or IL-1 $\beta+$ IFN- $\gamma$ (striped bars). Data are mean \pm S.E.M. of 4-7 independent experiments. ${ }^{*} P<0.05$; ${ }^{*} P<0.01$ versus ctrl. (c) Quantitative RT-PCR analyses of Crtc2 over L27 mRNA levels in INS-1E cells transfected with a Crtc2-coding plasmid or a control empty vector (ctrl). Data are mean \pm S.E.M. of four independent experiments. ${ }^{*} P<0.01$ versus respective empty vector transfection. (d) Luciferase activity in INS-1E cells cotransfected with various GJD2 promoter constructs and a control empty vector (ctrl; black bars) or the Crtc2-coding plasmid (Crtc2; white bars). Data are mean \pm S.E.M. of five independent experiments. ${ }^{*} P<0.05 ;{ }^{* *} P<0.01$ versus empty vector transfection. (e) Quantitative RT-PCR analyses of Cx36 over L27 mRNA levels in INS-1E cells transfected with a control plasmid (ctrl) or the Crtc2-coding plasmid (Crtc2) and treated or not (black bars) for $24 \mathrm{~h}$ with IL-1 $\beta+$ IFN- $\gamma$ (white bars). Data are mean \pm S.E.M. of four independent experiments. ${ }^{*} P<0.01$ versus untreated cells. ${ }^{\#} P<0.05$ versus respective empty vector transfection 


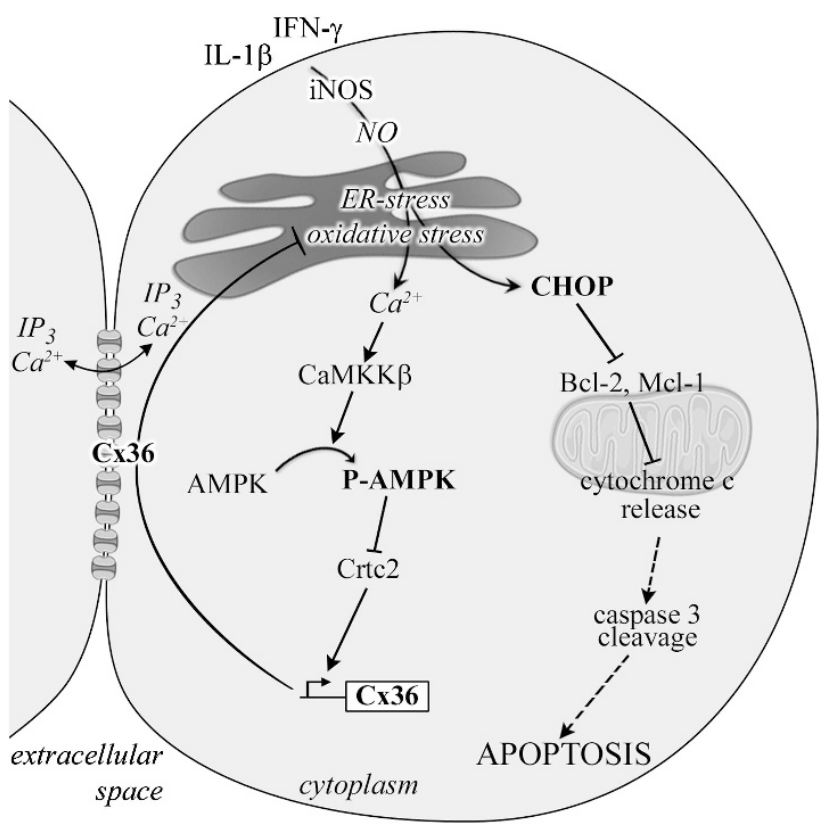

Figure 8 Cx36 has a central role in cytokine-induced ER stress, AMPK regulation and apoptosis. Pro-inflammatory cytokines stimulate NO production, leading to ER stress and increased CHOP expression. The ER stress-mediated $\left[\mathrm{Ca}^{2+}\right]_{1}$ increase promotes $\mathrm{CaMKK} \beta$ activation, resulting in AMPK phosphorylation, inhibition of $\mathrm{Crtc2}$ and the subsequent $\mathrm{C} \times 36$ downregulation. The decline in $\mathrm{C} \times 36$ levels aggravates ER stress, leading to increased CHOP overexpression, which in turn facilitates the degradation of the anti-apoptotic proteins $\mathrm{Bcl}-2$ and $\mathrm{Mcl}-1$, leading to cytochrome $\mathrm{c}$ release and, eventually, apoptosis. In a feedback loop, the reduced Cx36 levels facilitate AMPK phosphorylation, which further contributes to decrease in the levels of $\mathrm{C} \times 36$ and to worsening of the ER stress

these mechanisms, specifically those contributing to the $\beta$-cell apoptosis induced by the pro-inflammatory cytokines involved in the pathophysiology of type 1 diabetes. ${ }^{5}$ Here, we first demonstrate that cytokines and chemical ER stressors decrease the expression of $\mathrm{Cx} 36$ by downregulating the transcription of the cognate GJD2 gene. This effect requires the $\mathrm{Ca}^{2+}$-mediated activation of AMPK by $\mathrm{CaMKK} \beta$, and the subsequent inhibition of Crtc2, a CREB cofactor that modulates the activity of the GJD2 promoter. By altering the expression of Cx36 using siRNA and adenoviral gene transfer strategies, we then document that the knockdown of Cx36 sensitizes insulin-producing cells to the apoptosis induced by pro-inflammatory cytokines (IL-1 $\beta$, TNF- $\alpha$ and IFN- $\gamma$ ), whereas the overexpression of $\mathrm{Cx} 36$ protects against this effect. We further document that these effects correlate with oxidative stress. Thus, the knockdown of Cx36 increases the cytokine-induced production of both ROS and NO, whereas the overexpression of Cx36 prevents against this effect. Although more studies are required to carefully assess the impact of $\mathrm{C} \times 36$ on $\mathrm{ER} \mathrm{Ca}^{2+}$ levels, the study of ER $\mathrm{Ca}^{2+}$ release in the cytosol also suggest that $\mathrm{Cx} 36$ overexpression increases the basal ER $\mathrm{Ca}^{2+}$ levels. As a result, Cx36 overexpression dampens the depleting effect of cytokines on INS-1E cells and subsequent stress at the level of the ER. Accordingly, Cx36 overexpression lessens the effects of cytokines on ER stress-induced overexpression of CHOP, degradation of anti-apoptotic proteins $\mathrm{Mcl}-1$ and $\mathrm{Bcl}-2$, release of intra-mitochondrial cytochrome c, caspase 3 cleavage and, ultimately, apoptosis. Together, the activation of the mitochondria-dependent apoptosis and the concurrent downregulation of Cx36 following ER stress and the subsequent AMPK activation may contribute to the impairment of the $\beta$-cell resistance to cytokines (Figure 8).

Cytokines trigger ER stress in $\beta$-cells in an NO-dependent manner, through the downregulation of Serca2 and the subsequent depletion of ER $\mathrm{Ca}^{2+}$ stores. ${ }^{15}$ Cytokines are also known to stimulate AMPK activity in $\beta$-cells, ${ }^{26}$ but the mechanisms underlying this activation remained unclear. Here we show that AMPK activation requires the production of $\mathrm{NO}$, and can be achieved with thapsigargin but not with tunicamycin, suggesting that the depletion of $\mathrm{ER} \mathrm{Ca}^{2+}$ and the subsequent increase in cytosolic $\mathrm{Ca}^{2+}$ concentration, rather than the ER stress per se, trigger the activation of the kinase. The activation of the AMPK complex is controlled by several upstream kinases, ${ }^{13}$ including the constitutively active kinase LKB1 $1^{19,27-29}$ and the $\mathrm{Ca}^{2+}$-activated CaMKKs. ${ }^{19,30,31}$ Our data demonstrate that cytokines and thapsigargin phosphorylate AMPK via both LKB1 and CaMMK $\beta$, but that only the latter kinase controls the expression of $\mathrm{Cx36}$ in INS-1E cells. This discrepancy between AMPK and Cx36 regulation may be due to the fact that $\beta$-cells express both $\mathrm{AMPK} \alpha 1$ and $\mathrm{AMPK} \alpha 2,{ }^{32}$ two isoforms with partly redundant actions, but different localizations ${ }^{32}$ and preferential targets. ${ }^{33-35}$ The negative effect of AMPK on Cx36 transcriptional activity is mediated by inhibition of Crtc2, and it could be that only a CaMKK $\beta$-activated pool of AMPK is inhibiting Crtc2 and Cx36 expression.

We have previously shown that diabetogenic conditions such as high glucose, palmitate and/or oxidized LDL particles downregulate the expression of the Cx36 gene GJD2 through a cAMP/PKA-dependent overexpression of the repressor ICER-1/ICER-1 $\gamma{ }^{21,36}$ The present study unveils a novel pathway whereby cytokines downregulate Cx36 expression through a $\mathrm{Ca}^{2+}$ - and $\mathrm{CaMMK} \beta$-dependent activation of AMPK. We further document that the levels of AMPK, Cx36 and cell apoptosis are tightly related. Our data extend the notion that a persistent activation of AMPK leads to $\beta$-cell apoptosis, which has been suggested to involve the $c$-jun $\mathrm{N}$-terminal kinase ${ }^{37,38}$ as well as the anti-apoptotic mTOR pathways. ${ }^{39}$ We propose that $\mathrm{C} \times 36$ downregulation is an additional pro-apoptotic mechanism explaining the deleterious impact of sustained AMPK activation on $\beta$-cell survival. Strikingly, the downregulation of Cx36 triggers a feedback loop, whereby the decreased connexin expression enhances the cytokine-induced ER stress, the activation of AMPK and the overexpression of $\mathrm{CHOP}$, leading to further $\mathrm{Cx} 36$ downregulation and, eventually, apoptosis (Figure 8).

The sequence of events induced by cytokines leading to $\beta$-cell apoptosis is still incompletely understood. Here, we observe that $\mathrm{Cx} 36$ overexpression decreases the cytokineinduced production of ROS, but that neither the knockdown nor the overexpression of $\mathrm{Cx36}$ influences the basal and the cytokine-induced production of NO (data not shown). ${ }^{4}$ This indicates that the effect of Cx36 on ROS-RNS production occurs downstream the generation of NO. Furthermore, since Cx36 overexpression protects INS-1E cells against the thapsigargin-induced apoptosis, the cytokine-induced ROS 
production is likely to be secondary to the release of $\mathrm{ER} \mathrm{Ca}^{2+}$ and to the ensuing ER stress. Our data suggest that the cytosolic concentration of free $\mathrm{Ca}^{2+}$ has a central role in the cross talk between ER stress, AMPK activity and Cx36 signaling and regulation. This is consistent with previous studies showing a critical role of the cation in the activation of ER stress, the generation of ROS, the control of mitochondrial function ${ }^{40}$ and the activation of AMPK. ${ }^{41}$ Cx36 overexpression increases the basal $\mathrm{Ca}^{2+}$ stores of ER and prevents their depletion after exposure to cytokines (present data), whereas loss of Cx36 impairs the intercellular synchronization of $\mathrm{Ca}^{2+}$ transients, ${ }^{42-45}$ whose generation requires proper $\mathrm{ER} \mathrm{Ca}^{2+}$ stores. ${ }^{46}$ The homeostasis of ER $\mathrm{Ca}^{2+}$ is controlled by many factors, including inositol 1,4,5-trisphosphate (IP3), which can permeate gap junctions and contribute to mitochondrial apoptosis. ${ }^{47}$ Therefore, it is plausible that, by allowing the intercellular diffusion of $\mathrm{Ca}^{2+}$ and/or IP3, Cx36 channels achieve a sufficient dilution of harmful signals across the population of coupled cells, thus preventing the activation of mitochondrial apoptosis. ${ }^{4}$ Consistent with this hypothesis, Cx36 specifically hampers the intrinsic mitochondrial pathway of apoptosis by modulating the effect of cytokines on the $\mathrm{Ca}^{2+}$ stores of the ER and on the expression of the $\mathrm{CHOP}, \mathrm{Bcl}-2$ and $\mathrm{Mcl}-1$ proteins. These data further confirm our previous findings that $\mathrm{CHOP}$ has an important role in cytokine-induced apoptosis of insulin-producing cells by altering the stability of the $\mathrm{Bcl}-2$ and $\mathrm{Mcl}-1$ proteins. ${ }^{12}$

Overall, our data document that, by preserving the ER $\mathrm{Ca}^{2+}$ stores, Cx36-mediated intercellular communication prevents the cytokine-mediated ER stress, the subsequent activation of AMPK and the mitochondria-dependent apoptosis of INS-1E cells (Figure 8). Altogether, our data underscore the novel, central roles of AMPK and Cx36 in the pro-apoptotic events leading to $\beta$-cell apoptosis. In this scenario, innovative therapeutic approaches to interfere with the $\beta$-cell destruction in the context of T1D should benefit of the association of drugs restricting AMPK activation and of drugs promoting the expression and function of $\mathrm{Cx} 36$. The availability of novel methods for the screening of such specifically targeted drugs $^{43,48}$ will be instrumental to test this exciting possibility.

\section{Materials and Methods}

Materials. The following chemicals were purchased from Sigma-Aldrich NV/SA (Bornem, Belgium) and used as indicated: A23187 $(1 \mu \mathrm{M})$, thapsigargin $(100 \mathrm{nM}$ or $5 \mu \mathrm{M})$, tunicamycin $(5 \mu \mathrm{g} / \mathrm{ml})$ and STO-609 $(10 \mu \mathrm{M})$ were dissolved in DMSO; NG-Methyl-L-arginine (L-NMMA, $1 \mathrm{mM}$ ), sodium nitroprusside (SNP; $100 \mu \mathrm{M}$ ) and $\mathrm{N}$-acetyl-cystein (NAC; $1 \mathrm{mM}$ ) were dissolved in distilled water. The following cytokines were used: recombinant human IL-1 $\beta$ (R\&D systems, Abingdon, UK) at $10 \mathrm{U} / \mathrm{ml}$ in experiments with INS-1E cells; recombinant rat IFN- $\gamma$ (R\&D systems) at $100 \mathrm{U} / \mathrm{ml}(7.2 \mathrm{ng} / \mathrm{ml})$ in experiments with INS-1E cells; ${ }^{15,16}$ recombinant human TNF- $\alpha$ (R\&D systems) at $1000 \mathrm{U} / \mathrm{ml}$ in all experiments. The concentrations of chemicals and cytokines were selected based on our previous dose-response studies. ${ }^{15}$

Cells and islets. The rat insulinoma cell line INS-1E (kindly provided by Professor Pierre Maechler, CMU, University of
Geneva) was maintained in complete RPMI 1640 medium, as previously described. ${ }^{16,21} \mathrm{C} 57 \mathrm{BI} / \mathrm{J}$ mice and male Wistar rats (Janvier, St Berthevin, France) islets were isolated by collagenase digestion followed by hand picking under a stereomicroscope. ${ }^{16,21}$ Mouse and rat care, surgery and euthanasia procedures were approved by the Centre Hospitalier Universitaire Vaudois (CHUV) and the Cantonal Veterinary Office (Service de la Consommation et des Affaires Vétérinaires SCAV-EXPANIM).

RNA isolation and quantitative RT-PCR. Cells were homogenized in Tripure Isolation Reagent (Roche Diagnostics AG, Rotkreuz, Switzerland) and total RNA was extracted using the kit procedure. Transcripts $(1 \mu \mathrm{g})$ were reverse-transcribed using ImProm-II Reverse transcription System (Catalys AG, Wallisellen, Switzerland). Quantitative PCR was performed in a StepOne plus apparatus, using the Applied Biosystems Fast SYBR Green Master mix (Life Technologies Europe B.V., Zug, Switzerland). The primers used for amplification are given in Supplementary Table S1. Expression values were normalized to the ribosomal protein L27 (Rpl27).

Immunofluorescence. INS-1E cells grown on glass coverslips were fixed for $5 \mathrm{~min}$ in $-20^{\circ} \mathrm{C}$ acetone, air-dried, rinsed in PBS and permeabilized for $1 \mathrm{~h}$ in PBS supplemented with $1.5 \%$ BSA and $0.1 \%$ Triton X-100 (full PBS). Cytochrome c was immunostained on INS-1E cells fixed for $5 \mathrm{~min}$ in $4 \%$ ice-cold PFA, rinsed in PBS and permeabilized for $1 \mathrm{~h}$ in full PBS. In both cases, the coverslips were incubated overnight at $4{ }^{\circ} \mathrm{C}$ in the presence of either a rabbit polyclonal serum against Cx36 (dilution 1/100; Invitrogen) or a mouse monoclonal against cytochrome c (1/1000; BD Biosciences, Allschwil, Swizterland). Cells were then washed and further exposed for $1 \mathrm{~h}$ to an appropriate Alexa fluor 488- or 555conjugated antibody (1/1000; Life Technologies Europe B.V.) and photographed under fluorescence microscopy (Leica Camera AG, Nidau, Switzerland). Quantitative assessment of the membrane spots immunostained by the Cx36 antibodies was performed using the ImageJ software. Briefly, 30 images from 3 distincts experiments were first converted to a 32-bit format and the signal-to-noise ratio was determined by applying the Yen thresholding method. ${ }^{49}$ A binary image was then created and the pixel intensity of the Cx36 signal was calculated. Data were normalized to the number of cells in each image.

Transient transfection and promoter reporter assays. INS-1E cells were transiently transfected using lipofectamine 2000 (Life Technologies Europe B.V.) as previously described. ${ }^{22,36}$ The CaMKK $\alpha$ and $\beta$ CDS plasmids cloned in PCDNA3 were kindly provided by Dr Angela Woods (MRC Clinical Science Centre, Imperial College, Hammersmith Hospital, London, England). The mouse Crtc2 CDS plasmid was purchased from Origene (OriGene Technologies, Rockville, MD, USA). Promoter studies were performed using various fragments of the promoter of the human Cx36 gene GJD2, which was cloned in the pGL3-basic reporter plasmid, as previously described. ${ }^{36}$ The Luciferase plasmids were cotransfected with the internal control pRL-CMV encoding 
Renilla luciferase (Promega, Madison, WI, USA). The transcriptional activity of GJD2 was assessed using the Dual-Luciferase reporter assay system (Catalys AG) in a Turner TD-20/20 Luminometer. ${ }^{21}$ The activity of the GJD2 promoter was normalized to that induced by the pRL-CMV plasmid, which was cotransfected.

Western blot analysis. Cells were washed once with cold PBS and immediately lysed in Laemmli buffer as previously described. $^{16,21}$ Lysates were resolved by SDS-PAGE and transferred to a PVDF membrane. Immunoblot analyses were performed as previously described, ${ }^{16,21}$ using the following antibodies: rabbit polyclonal antibodies against Cx36 diluted $1: 200 ;{ }^{21,36}$ rabbit polyclonal anti P-AMPK $\alpha 1$ and $\alpha 2$, diluted 1:1000; rabbit polyclonal anti-total AMP$\mathrm{K} \alpha 1, \alpha 2$, diluted 1:2000; rabbit polyclonal anti-LKB1, diluted 1:1000; polyclonal anti-cleaved caspase 3, diluted 1:1000 from Cell Signaling Boston, MA, USA; polyclonal anti-Bcl-2, diluted 1:1000; polyclonal anti-CHOP/GADD153, diluted $1: 1000$ and polyclonal anti-Bax, diluted 1:1000; from Santa Cruz Biotechnology, Santa Cruz, CA, USA; rabbit anti-rat Mcl-1 (Biovision, LuBioScience $\mathrm{GmbH}$, Lucerne, Switzerland) diluted 1:500; monoclonal anti- $\alpha$-tubulin and horseradish peroxidase-conjugated goat anti-rabbit or anti-mouse IgG (Sigma-Aldrich), diluted 1:5000.

RNA interference and adenoviral cell infection. Rat Cx36 Silencer Select pre-designed siRNA s132237 (siCx36\#1) and s132238 (siCx36\#2) and rat LKB1 Silencer Select pre-designed siRNA s163339 (siLKB1\#1) and s163340 (siLKB1\#2) were from Applied Biosystems (Life Technologies Europe B.V.). The Allstars Negative Control siRNA (Qiagen, Hombrechtikon, Switzerland), which has no effect on $\beta$-cell gene expression and viability, ${ }^{12,16,50}$ was used as a control. siRNA transfections were conducted as previously described using lipofectamin RNAiMax (Life Technologies Europe B.V.) and $30 \mathrm{nM}$ siRNA. The efficiency of transfection was $>90 \%$ of the cells. ${ }^{12,16,50}$ The Control Ad-GFP and Ad-Cx36 viruses were generated as previously described. ${ }^{21,22}$ Ad-DN-AMPK was a kind gift from Professor Bernard Thorens, University of Lausanne, Switzerland. ${ }^{51}$ All viral vectors were amplified and purified by Vector Biolabs, Philadelphia, PA, USA. Adenoviral infections were conducted as previously described. ${ }^{16,22,52}$

ROS and/or RNS and superoxide measurements. The ROS-RNS and superoxide production were measured using the total ROS and Superoxide Detection Kit (Enzo Life Sciences AG, Lausen, Switzerland) as previously described. $^{25}$ Briefly, INS-1E cells were plated in 96-well plates. Cells were transfected or infected as previously described and then treated for $24 \mathrm{~h}$ with IL-1 $\beta+\mathrm{IFN}-\gamma$. As a positive control, INS-1E cells were treated for $30 \mathrm{~min}$ with $200 \mu \mathrm{M}$ of the ROS inducer pyocyanin. INS-1E cells were then washed once and incubated for $30 \mathrm{~min}$ in $100 \mu \mathrm{l}$ buffer containing $2 \mu \mathrm{M}$ oxidative stress detection reagent (green) and $2 \mu \mathrm{M}$ superoxide detection reagent (orange). Fluorescence was quantified using the Synergy Mx MonochromatorBased Multi-Mode Microplate Reader (BioTek AG, Luzern, Switzerland) and fluorescein $(E x=488 \mathrm{~nm}, E m=520 \mathrm{~nm})$ and rhodamine $(E x=550 \mathrm{~nm}, E m=610 \mathrm{~nm})$ filter sets.
Cytosolic calcium monitoring. Cells were washed once in $\mathrm{KRBH}\left(20 \mathrm{mM} \mathrm{NaCl}, 3.5 \mathrm{mM} \mathrm{KCl}, 0.5 \mathrm{mM} \mathrm{NaH} \mathrm{PO}_{4}, 1.5 \mathrm{mM}\right.$ $\mathrm{CaCl}_{2}, 5 \mathrm{mM} \mathrm{NaHCO} 3,10 \mathrm{mM}$ HEPES and $5 \mathrm{mM}$ glucose) and incubated for $30 \mathrm{~min}$ in the same solution supplemented with $3 \mu \mathrm{M}$ Fura-2/AM (Life Technologies Europe B.V.), in the dark and at $37^{\circ} \mathrm{C}$. Loaded cells were washed in $\mathrm{Ca}^{2+}$-free $\mathrm{KRBH}$ containing $0.1 \mathrm{mM}$ EGTA and observed under a Zeiss inverted microscope (x40 oil immersion fluorescence objective). Fura-2AM was excited at $340 / 380 \mathrm{~nm}$ with a Visichrome holographic monochromator (Visitron Systems $\mathrm{GmbH}$, Puchheim, Germany) and emission fluorescence was monitored at $510 \mathrm{~nm}$ using a Hamamatsu Orca ER coded CCD Camera (Hamamatsu, Solothurn, Switzerland). Images were treated with MetaFluor (Molecular Devices France, St. Grégoire, France) to evaluate the ratio of fluorescence emitted at 340 and $380 \mathrm{~nm}$.

Assessment of cell viability. The percentage of viable, apoptotic and necrotic cells was determined using the DNAbinding dyes propidium iodide (PI, $5 \mu \mathrm{g} / \mathrm{ml}$ ) and Hoechst $33342\left(\mathrm{HO}, 5 \mu \mathrm{g} / \mathrm{ml}\right.$, Sigma-Aldrich). ${ }^{15}$ The cells were examined by inverted fluorescence microscopy (Axiovert 200, Carl Zeiss, Zaventem, Belgium). A minimum of 500 cells were counted in each experimental condition by two independent observers, one of them unaware of the sample identity.

Cell coupling. Three-day-old cultures of INS-1E cells were exposed for $24 \mathrm{~h}$ to RPMI 1640 medium supplemented with either $10 \mathrm{U} / \mathrm{ml} \mathrm{IL}-1 \beta$ or $2 \mathrm{mM}$ metformin. The dishes were then transferred onto the heated $\left(37^{\circ} \mathrm{C}\right)$ stage of an inverted Zeiss ICM35 microscope, and individual cells were microinjected using glass pipettes containing 4\% Lucifer Yellow CH (SigmaAldrich, St Louis, MO, USA) in 10 mM Hepes-buffered ( $\mathrm{pH} 7.2$ ) $150 \mathrm{mM} \mathrm{LiCl}$ and square negative pulses of $0.1 \mathrm{nA}$ amplitude, $900 \mathrm{~ms}$ duration and $0.5 \mathrm{~Hz}$ frequency. Coupling extent was calculated after each injection by scoring the number of cells containing the injected tracer. Coupling incidence was determined by calculating the percentage of injections resulting in the cell-to-cell transfer of the tracers. Coupling index was given by coupling extent $\times$ coupling incidence.

Statistical analysis. Data are presented as mean \pm S.E.M. Comparisons were performed by two-tailed paired Student's $t$-test or by one-way ANOVA followed by t-tests with Bonferroni correction for multiple comparisons. Coupling incidence was compared by the $\chi^{2}$-test. A $P$-value $\leq 0.05$ was considered statistically significant.

\section{Conflict of Interest}

The authors declare no conflict of interest.

Acknowledgements. This work was supported by grants from the SNF (31003A-138528; 310030_141162; CR32I3_129987), the JDRF (40-2011-11; 5-2012-281; 1-2011-589), the EU (BETAIMAGE 222980; IMIDIA, C2008-T7; BETATRAIN 289932), NIH HL64232, the Novartis Foundation and the Emma Muschamp Foundation, FNRS-MIS- Belgium (F.4521.11).

1. Bosco D, Haefliger JA, Meda P. Connexins: key mediators of endocrine function. Physiol Rev 2011; 91: 1393-1445.

2. Cigliola V, Chellakudam V, Arabieter W, Meda P. Connexins and beta-cell functions. Diabetes Res Clin Pract 2013; 99: 250-259. 
3. Decrock E, Vinken M, De Vuyst E, Krysko DV, D'Herde K, Vanhaecke T et al. Connexinrelated signaling in cell death: to live or let die? Cell Death Differ 2009; 16: 524-536.

4. Klee $P$, Allagnat $F$, Pontes $H$, Cederroth $M$, Charollais $A$, Caille $D$ et al. Connexins protect mouse pancreatic beta cells against apoptosis. J Clin Invest 2011; 121: 4870-4879.

5. Eizirik DL, Colli ML, Ortis F. The role of inflammation in insulitis and beta-cell loss in type 1 diabetes. Nat Rev Endocrinol 2009; 5: 219-226.

6. Thomas HE, McKenzie MD, Angstetra E, Campbell PD, Kay TW. Beta cell apoptosis in diabetes. Apoptosis 2009; 14: 1389-1404.

7. Robertson RP. Beta-cell deterioration during diabetes: what's in the gun? Trends Endocrinol Metab 2009; 20: 388-393.

8. Gurzov EN, Eizirik DL. Bcl-2 proteins in diabetes: mitochondrial pathways of beta-cell death and dysfunction. Trends Cell Biol 2011; 21: 424-431.

9. Youle RJ, Strasser A. The BCL-2 protein family: opposing activities that mediate cell death. Nat Rev Mol Cell Biol 2008; 9: 47-59.

10. Rasola A, Bernardi P. Mitochondrial permeability transition in $\mathrm{Ca}(2+)$-dependent apoptosis and necrosis. Cell Calcium 2011; 50: 222-233.

11. Rizzuto R, De Stefani D, Raffaello A, Mammucari C. Mitochondria as sensors and regulators of calcium signalling. Nat Rev Mol Cell Biol 2012; 13: 566-578.

12. Allagnat F, Fukaya M, Nogueira TC, Delaroche D, Welsh N, Marselli $L$ et al. C/EBP homologous protein contributes to cytokine-induced pro-inflammatory responses and apoptosis in beta-cells. Cell Death Differ 2012; 19: 1836-1846.

13. Hardie DG, Ross FA, Hawley SA. AMPK: a nutrient and energy sensor that maintains energy homeostasis. Nat Rev Mol Cell Biol 2012; 13: 251-262.

14. Scorrano L. Opening the doors to cytochrome $\mathrm{C}$ : changes in mitochondrial shape and apoptosis. Int J Biochem Cell Biol 2009; 41: 1875-1883.

15. Cardozo AK, Ortis F, Storling J, Feng YM, Rasschaert J, Tonnesen M et al. Cytokines downregulate the sarcoendoplasmic reticulum pump $\mathrm{Ca} 2+$ ATPase $2 \mathrm{~b}$ and deplete endoplasmic reticulum $\mathrm{Ca} 2+$, leading to induction of endoplasmic reticulum stress in pancreatic beta-cells. Diabetes 2005; 54: 452-461.

16. Allagnat F, Cunha D, Moore F, Vanderwinden JM, Eizirik DL, Cardozo AK. Mcl-1 downregulation by pro-inflammatory cytokines and palmitate is an early event contributing to beta-cell apoptosis. Cell Death Differ 2011; 18: 328-337.

17. Lemmens R, Larsson O, Berggren PO, Islam MS. Ca2 + -induced Ca2 + release from the endoplasmic reticulum amplifies the $\mathrm{Ca} 2+$ signal mediated by activation of voltage-gated L-type Ca2 + channels in pancreatic beta-cells. J Biol Chem 2001; 276: 9971-9977.

18. Chen L, Koh DS, Hille B. Dynamics of calcium clearance in mouse pancreatic beta-cells. Diabetes 2003; 52: 1723-1731.

19. Fogarty S, Hawley SA, Green KA, Saner N, Mustard KJ, Hardie DG. Calmodulindependent protein kinase kinase-beta activates AMPK without forming a stable complex: synergistic effects of $\mathrm{Ca} 2+$ and AMP. Biochem J 2010; 426: 109-118.

20. Tokumitsu H, Inuzuka H, Ishikawa Y, Ikeda M, Saji I, Kobayashi R. STO-609 a specific inhibitor of the $\mathrm{Ca}(2+) /$ calmodulin-dependent protein kinase kinase. J Biol Chem 2002; 277: 15813-15818

21. Allagnat F, Alonso F, Martin D, Abderrahmani A, Waeber G, Haefliger JA. ICER-1gamma overexpression drives palmitate-mediated connexin36 down-regulation in insulin-secreting cells. J Biol Chem 2008; 283: 5226-5234.

22. Haefliger JA, Martin D, Favre D, Petremand J, Mazzolai L, Abderrahmani A et al. Reduction of Connexin36 content by ICER-1 contributes to insulin-secreting cells apoptosis induced by oxidized LDL particles. PLOS One 2013; 8: e55198.

23. Lee JM, Seo WY, Song KH, Chanda D, Kim YD, Kim DK et al. AMPK-dependent repression of hepatic gluconeogenesis via disruption of CREB.CRTC2 complex by orphan nuclear receptor small heterodimer partner. J Biol Chem 2010; 285: 32182-32191.

24. Fu A, Screaton RA. Using kinomics to delineate signaling pathways: control of CRTC2/ TORC2 by the AMPK family. Cell Cycle 2008; 7 : 3823-3828.

25. Haefliger JA, Martin D, Favre D, Petremand Y, Mazzolai L, Abderrahmani A et al. Reduction of connexin36 content by ICER-1 contributes to insulin-secreting cells apoptosis induced by oxidized LDL particles. PLoS One 2013; 8: e55198.

26. Riboulet-Chavey A, Diraison F, Siew LK, Wong FS, Rutter GA. Inhibition of AMP-activated protein kinase protects pancreatic beta-cells from cytokine-mediated apoptosis and CD8 + T-cell-induced cytotoxicity. Diabetes 2008; 57: 415-423.

27. Ollila S, Makela TP. The tumor suppressor kinase LKB1: lessons from mouse models. J Mol Cell Biol 2011; 3: 330-340.

28. Lizcano JM, Goransson O, Toth R, Deak M, Morrice NA, Boudeau J et al. LKB1 is a master kinase that activates 13 kinases of the AMPK subfamily, including MARK/PAR-1. Embo J 2004; 23: 833-843.

29. Hawley SA, Boudeau J, Reid JL, Mustard KJ, Udd L, Makela TP et al. Complexes between the LKB1 tumor suppressor, STRAD alpha/beta and MO25 alpha/beta are upstream kinases in the AMP-activated protein kinase cascade. J Biol 2003; 2: 28.
30. Woods A, Dickerson K, Heath R, Hong SP, Momcilovic M, Johnstone SR et al. Ca2 + I calmodulin-dependent protein kinase kinase-beta acts upstream of AMP-activated protein kinase in mammalian cells. Cell Metab 2005; 2: 21-33.

31. Hawley SA, Pan DA, Mustard KJ, Ross L, Bain J, Edelman AM et al. Calmodulindependent protein kinase kinase-beta is an alternative upstream kinase for AMP-activated protein kinase. Cell Metab 2005; 2: 9-19.

32. da Silva Xavier G, Leclerc I, Salt IP, Doiron B, Hardie DG, Kahn A et al. Role of AMPactivated protein kinase in the regulation by glucose of islet beta cell gene expression. Proc Natl Acad Sci USA 2000; 97: 4023-4028.

33. Woods A, Salt I, Scott J, Hardie DG, Carling D. The alpha1 and alpha2 isoforms of the AMP-activated protein kinase have similar activities in rat liver but exhibit differences in substrate specificity in vitro. FEBS Lett 1996; 397: 347-351.

34. Klaus A, Polge C, Zorman S, Auchli Y, Brunisholz R, Schlattner U. A two-dimensional screen for AMPK substrates identifies tumor suppressor fumarate hydratase as a preferential AMPKalpha2 substrate. J Proteomics 2012; 75: 3304-3313.

35. Witczak CA, Sharoff CG, Goodyear LJ. AMP-activated protein kinase in skeletal muscle: from structure and localization to its role as a master regulator of cellular metabolism. Cell Mol Life Sci 2008; 65: 3737-3755

36. Allagnat F, Martin D, Condorelli DF, Waeber G, Haefliger JA. Glucose represses connexin36 in insulin-secreting cells. J Cell Sci 2005; 118(Pt 22): 5335-5344.

37. Kefas BA, Cai $Y$, Kerckhofs $K$, Ling Z, Martens G, Heimberg $H$ et al. Metformininduced stimulation of AMP-activated protein kinase in beta-cells impairs their glucose responsiveness and can lead to apoptosis. Biochem Pharmacol 2004; 68 : 409-416.

38. Kefas BA, Cai Y, Ling Z, Heimberg H, Hue L, Pipeleers D et al. AMP-activated protein kinase can induce apoptosis of insulin-producing MIN6 cells through stimulation of c-Jun-N-terminal kinase. J Mol Endocrinol 2003; 30: 151-161.

39. Cai $Y$, Wang $Q$, Ling $Z$, Pipeleers $D$, McDermott $P$, Pende $M$ et al. Akt activation protects pancreatic beta cells from AMPK-mediated death through stimulation of mTOR. Biochem Pharmacol 2008; 75: 1981-1993.

40. Pinton P, Giorgi C, Siviero R, Zecchini E, Rizzuto R. Calcium and apoptosis: ER-mitochondria $\mathrm{Ca} 2+$ transfer in the control of apoptosis. Oncogene 2008; 27: 6407-6418.

41. Ahn YJ, Kim H, Lim H, Lee M, Kang Y, Moon S et al. AMP-activated protein kinase: implications on ischemic diseases. BMB Rep 2012; 45: 489-495.

42. Ravier MA, Guldenagel M, Charollais A, Gjinovci A, Caille D, Sohl G et al. Loss of connexin36 channels alters beta-cell coupling, islet synchronization of glucoseinduced $\mathrm{Ca} 2+$ and insulin oscillations, and basal insulin release. Diabetes 2005; 54 1798-1807.

43. Bavamian S, Pontes H, Cancela J, Charollais A, Startchik S, Van de Ville D et al. The intercellular synchronization of $\mathrm{Ca} 2+$ oscillations evaluates $\mathrm{C} \times 36$-dependent coupling PLoS One 2012; 7: e41535.

44. Head WS, Orseth ML, Nunemaker CS, Satin LS, Piston DW, Benninger RK. Connexin-36 gap junctions regulate in vivo first- and second-phase insulin secretion dynamics and glucose tolerance in the conscious mouse. Diabetes 2012; 61: 1700-1707.

45. Benninger RK, Zhang M, Head WS, Satin LS, Piston DW. Gap junction coupling and calcium waves in the pancreatic islet. Biophys J 2008; 95: 5048-5061.

46. Tengholm A, Gylfe E. Oscillatory control of insulin secretion. Mol Cell Endocrinol2009; 297 58-72.

47. Decrock E, Krysko DV, Vinken M, Kaczmarek A, Crispino G, Bol M et al. Transfer of IP(3) through gap junctions is critical, but not sufficient, for the spread of apoptosis. Cell Death Differ 2012; 19: 947-957.

48. McCullough LD, Zeng Z, Li H, Landree LE, McFadden J, Ronnett GV. Pharmacological inhibition of AMP-activated protein kinase provides neuroprotection in stroke. J Biol Chem 2005; 280: 20493-20502.

49. Yen JC, Chang FJ, Chang S. A new criterion for automatic multilevel thresholding IEEE Trans Image Proc 1995; 4: 370-378.

50. Moore AF, Jablonski KA, Mason CC, McAteer JB, Arakaki RF, Goldstein BJ et al. The association of ENPP1 K121Q with diabetes incidence is abolished by lifestyle modification in the diabetes prevention program. J Clin Endocrinol Metab 2009; 94: 449-455.

51. Foretz M, Ancellin N, Andreelli F, Saintillan Y, Grondin P, Kahn A et al. Short-term overexpression of a constitutively active form of AMP-activated protein kinase in the liver leads to mild hypoglycemia and fatty liver. Diabetes 2005; 54: 1331-1339.

52. Allagnat $F$, Christulia $F$, Ortis $F$, Pirot $P$, Lortz $S$, Lenzen $S$ et al. Sustained production of spliced X-box binding protein 1 (XBP1) induces pancreatic beta cell dysfunction and apoptosis. Diabetologia 2010; 53: 1120-1130. 